\title{
PLATO'S PILOT IN THE POLITICAL STRATEGY \\ OF JULIAN AND LIBANIUS
}

The rhetorical career of Libanius of Antioch (A.D. 314 - c. 393), spanned the reigns of a number of fourth-century emperors. Like many orators, he used the trope of the emperor as a pilot, steering the ship of state. He did this for his imperial exemplar Julian, and in fact for his predecessor Constantius II as well. Julian sought to craft an identity for himself as a theocratic king. He and his supporters cast him as an earthly parallel to the Christ-like versions of Heracles and Asclepius he constructed, which was arguably a co-opting of Christian and particularly Constantinian themes. ${ }^{1}$ In a public oration, Julian even placed himself in the role of Christ in the Temptation in the Wilderness. ${ }^{2}$ This kind of overtly Christian metaphor was not Libanius' preferred idiom, however, and he wrote of Julian as another kind of chosen and divine saviour figure, one with its roots in the golden age of Greek philosophy. The figure of the

1 D.N. Greenwood, 'Crafting divine personae in Julian's Oration 7', CPh 109, 140-49; D.N. Greenwood, 'Julian's Use of Asclepius Against the Christians', HSPh 109 (forthcoming 2018). The Latinized spellings of Greek names here will hopefully be familiar to the widest range of readers. * The text of Plato's Statesman is that of Burnet (Oxford, 1903), Libanius' Orations that of Foerster (Leipzig, 1904), Julian's works the text and numbering of the Budé edition (Paris, 1924-64), and Synesius' de Providentia that of the Budé edition (Paris, 1978-2008). All translations are my own unless otherwise noted.

2 D.N. Greenwood, 'A Pagan Emperor's Appropriation of Matthew's Gospel', The Expository Times 125 (2014), 593-98, comparing Julian, Or. 7 229c-233d (To the Cynic Heracleios) and Matthew 3.7-4.10. 


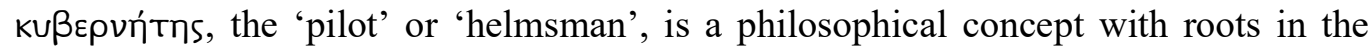
thought of the pre-Socratics, but most familiar from Plato. ${ }^{3}$ The uses of this metaphor by Julian and Libanius highlight the rhetorical strategy and self-presentation the emperor employed during his reign.

\section{THE PILOT AS IDEAL STATESMAN}

In Plato's writings, the pilot was both a metaphor for the ideal statesman, one who cared for both ship and sailors, as well as a divine figure who would right the world's

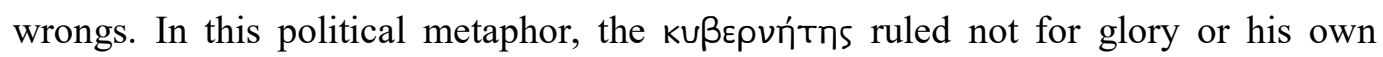
good, but for the benefit of his ship and crew. Plato wrote, 'Just as the pilot is always watching out for the common good of the ship and crew, not establishing written law,

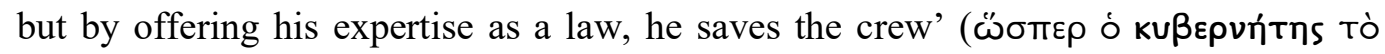

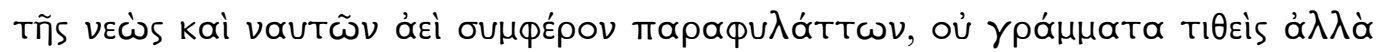

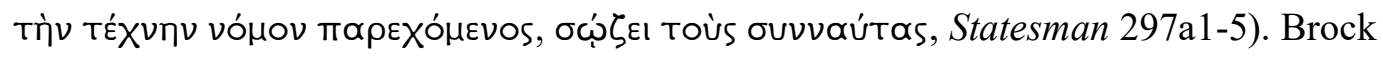

traces the development of the metaphor and highlights the central components, the claim based on 'ability and expertise', and the focus on the 'preservation of the community'. ${ }^{4}$ This political exemplar of the pilot as an ideal ruler was used extensively after Plato, and drawn upon by Libanius as well.

3 H.G. Liddell and R. Scott, Greek-English Lexicon (Oxford, 1998), 1004, s.v.

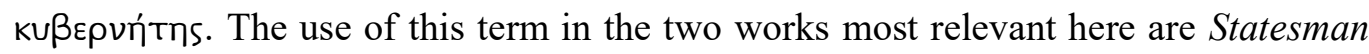
272e4, 296e4, 297e11, 273c3; Republic 332e2, 9, 333c3, 341c9, 341d2, 342d9, 349e2-3, 360e7, 389c4, 397e5, 488d4, 489b6.

$4 \quad$ R. Brock, Greek Political Imagery from Homer to Aristotle (London and New York, 2013), 56. 
In 363, Libanius described Julian as a great statesman in an oration in the metropolis of Antioch. During Julian's period of study in Nicomedia many years prior, he had had the rhetorician's lectures recorded for him. Libanius was one of many who were undoubtedly delighted by Julian's accession to sole rule in late $361 .{ }^{5}$ While it took several months for Libanius to gain access to Julian and his court after the emperor's arrival on 18 July 362, Libanius became entrenched in the emperor's circle. ${ }^{6}$ This delay may have been due to Julian's reserve towards a man who had so praised Constantius II in his Or. 59, Panegyric on Constantius and Constans. Despite the brevity of their closer association, Libanius was an enthusiastic supporter of Julian's revival, and in turn, the emperor referred to the orator as 'brother' and the most philosophical and truth-loving orator. ${ }^{7}$

On 1 January 363 in Antioch, Libanius delivered an oration on the occasion of Julian's consulship. ${ }^{8}$ This oration had something of a defensive tone, coming as it did following numerous escalating confrontations between the emperor and the largely

5 Libanius, Or. 13.14; for an estimation of pagan support for Julian's religious revival, see also D.N. Greenwood, 'Five Latin inscriptions from Julian's pagan restoration', BICS 57 (2014), 101-19.

$6 \quad$ H.-U. Wiemer, Libanios und Julian (Munich, 1995), 39; A.H.M. Jones, et al., Prosopography of the Later Roman Empire, vol. 1: A.D. 260-395 (Cambridge, 1971), 505; cf. Lib., Or. 1.51. Julian entered Antioch during the festival of Adonis: Amm. 22.9.15; O. Seeck, Regesten der Kaiser and Päpste für die Jahre 311 bis 476 n. Chr. (Stuttgart, 1919), 210.

$7 \quad$ Julian, Ep. 96.374d; Ep. 97.382c.

$8 \quad$ A.F. Norman (ed.), Libanius, Selected Works, Vol. 1: The Julianic Orations (Cambridge, Mass., 1969), 36. 
Christian population of the city. Over the period of seven to eight months following Julian's arrival in Antioch, communication broke down between the emperor and his Antiochene subjects. ${ }^{9}$ The catalyst was the particularly poor harvest of $362 .{ }^{10}$ In addition to the imperial court, the army Julian assembled for the invasion of Persia was very sizeable. ${ }^{11}$ This resulted in a severe grain shortage with which the curiales were unable to help the emperor. ${ }^{12}$ Julian insisted that the city leaders had refused to work towards a solution, added to which Liebeschuetz points out the conflict of interest as the curiales were also, by and large, the local grain producers. ${ }^{13}$ Julian responded by capping grain prices and directly providing additional grain, but without rationing it, leading to speculators snatching it up. ${ }^{14}$ In religious terms, things went even more poorly. Seeking to purify the shrine at Daphne, Julian had removed the body of St. Babylas, which local Christians turned into a triumph for the power of the saint. ${ }^{15}$ This was followed by the burning of the shrine, which Julian blamed on the

9 L. Van Hoof and P. Van Nuffelen, 'Monarchy and Mass Communication: Antioch A.D. 362/3 Revisited,' JRS 101 (2011), 166-84.

$10 \quad$ Amm. 22.13.14; Lib., Or. 18.195.

11 Julian admitted that the shortage was exacerbated by the mass of troops he brought with him; Or. 12.370 b (Misopogon).

$12 \quad$ Amm. 22.14.2; Lib. Or. 1.126; 16.21.

13 Julian, Or. 12.368d, 369d-370a (Misopogon); J.H.W.G. Liebeschuetz, Antioch: city and imperial administration in the later Roman Empire (Oxford, 1972), 130.

$14 \quad$ Julian, Or.12.369ab (Misopogon).

$15 \quad$ Amm. 22.12.8; Rufinus 10.36; Theodoret 3.6. 
Christians, closing the Great Church of Antioch in retaliation. ${ }^{16}$ In short, Julian's campaign to counter Constantine's Christianization in Antioch was showing signs of fatigue. Despite this, Libanius soldiered on and supported Julian with an address at the new year celebrating his consulship. Wiemer has shown the extent to which Libanius depended on Julian's Or. 5 To the Senate and People of Athens. ${ }^{17}$ The orator also made use several times of this nautical metaphor, which made appearances at key points in his oration.

First, Libanius referenced Julian's philosophically-driven rejection of Christianity, a strategic event he called 'the start of freedom ( $\dot{\lambda} \lambda \varepsilon v \theta \varepsilon p i \alpha$ ) for the world', writing of Julian and his mentor, Maximus of Ephesus, and how they 'passed through the Cyanean rocks' (traditionally the Bosporus, Or. 12.34). Second, after approvingly summing up Julian's history prior to being named Caesar by Constantius in A. D. 355, Libanius turned to his imperial career: 'Now let us test him as the pilot

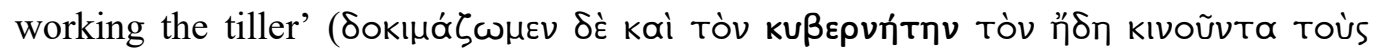
olıakas, Or. 12.42). Finally, once Julian had succeeded to undisputed rule, Libanius

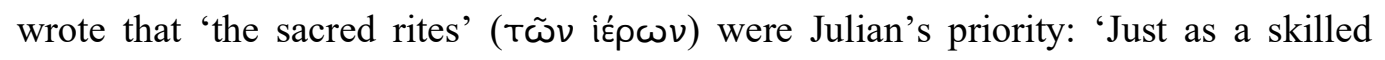

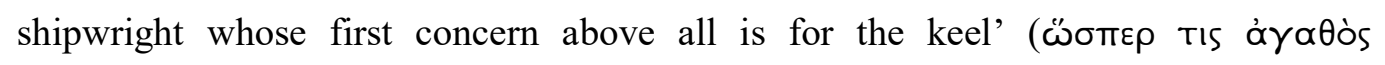

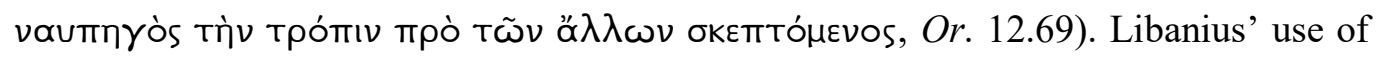
the figure of the shipwright, a skilled craftsman, calls to mind the TÉxvn of Plato's

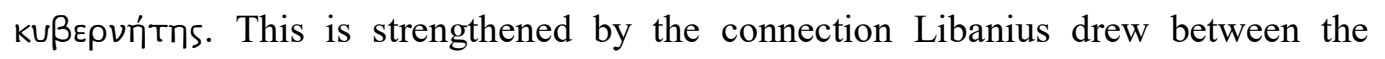
salvation of the ship and of the cities: 'For as the strength of this is the salvation of the

$16 \quad$ Amm. 22.13.1-3; Julian, Or. 12.361b (Misopogon); Theodoret 3.12.1; cf. W. Mayer and P. Allen, The Churches of Syrian Antioch (300-638 CE) (Leuven, 2012), 77.

$17 \quad$ Wiemer (n. 6), 162-4. 


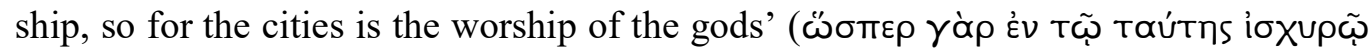

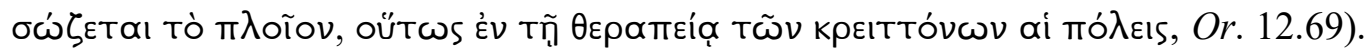
In this extended metaphor, Libanius made Julian the salvific actor on behalf of the world, the guardian of traditional religion, and the pilot for Hellenic culture, all using

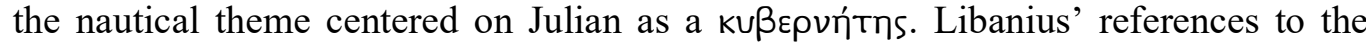
divine in connection to Julian are somewhat limited here, although Cribiore suggests that the description of 'Zeus, the consul of the gods' is an implicit comparison with Julian, the consul of men (Or. 12.14). ${ }^{18}$ These passages show Libanius' association of Julian with the figure of the Platonic Pilot, but in the sense of a statesman. In the previous year, Libanius had presented the emperor as a pilot, but using the same nautical metaphor in a divine sense.

\section{THE PILOT AS DIVINE RESTORER}

In the introduction to his edition of Plato's Statesman, Campbell contrasted the figure of Plato's pilot with mere sophists and party leaders, writing that there 'might be traced the footprints of a more august presence; of a Divine spirit "coming down in the likeness" of sage or legislator'. ${ }^{19}$ This idea of a divine restorert of the cosmos received further impetus in late antiquity, as the pilot took on a human figure and a

18 R. Cribiore, Libanius the Sophist: Rhetoric, Reality, and Religion in the Fourth Century (Ithaca and London, 2013), 217. Zeus Hypatos is a standard Homeric epithet, originally referring to elevation, but note the explicit comparison Libanius makes between Julian and Zeus in Or. 13.47 (see p. 9 and n. 27).

19 L. Campbell (ed.), The Sophistes and Politicus of Plato (Oxford, 1867), i. 
somewhat messianic role. This, again, drew upon Plato for material, this time with a cosmological application.

For Plato, the Cosmos was in perpetual motion, rotating according to design under the eye of the pilot, although upon his withdrawal, the Cosmos began to slow and counter-rotate, going against its design and bringing calamity upon earth: Now formerly the pilot of the universe released the tiller, as it were, and retreated to his conning-tower and both destiny and natural desire caused the Cosmos to turn

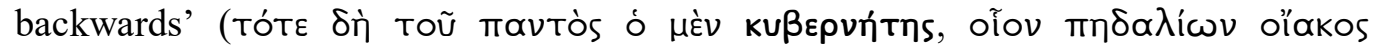

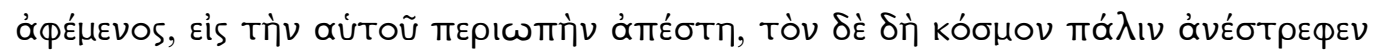

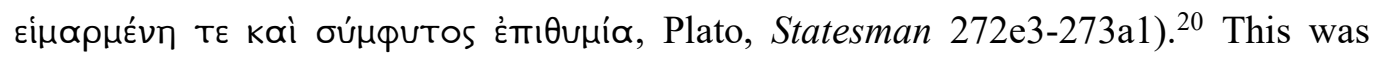
followed by the lesser gods abandoning their posts as well, adding to the chaos. At some point, the pilot would return and set the Cosmos aright, rotating in the right fashion again. God ( $\theta \varepsilon$ cós), who ordered the Cosmos, would naturally become concerned by the extent of its decline, and 'resumes his place at the helm' ( $\pi \alpha{ }^{\prime} \lambda_{I} v$

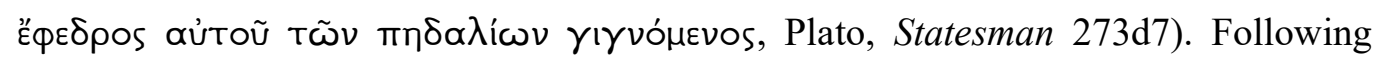

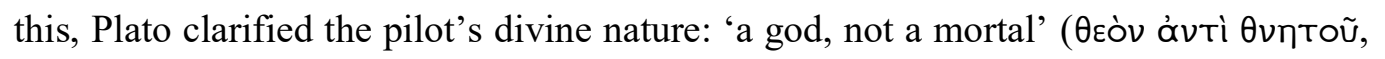
Plato, Statesman 275a4). Considerable latitude should be given to how literally this was taken. John Dillon has suggested that Neoplatonic reception of the Statesman indicates that it was interpreted allegorically in that period. ${ }^{21}$ This freed interpreters to make rather flexible use of the metaphor. Libanius made use of this concept in ways

20 See also discussion of this passage in M.S. Lane, Method and Politics in Plato's Statesman (Cambridge, 1998), 102-3; F.M. Cornford, Plato's Cosmology (London, 1937), 207.

${ }^{21}$ J. Dillon, ‘The theology of Julian’s Hymn to King Helios’ Itaca 14-15 (1995), $103-15$. 
that could at first glance be taken as referring either to an ideal statesman or to a divine figure, until the context is considered.

At Julian's request, in July 362, Libanius delivered his Or. 13, An Address to

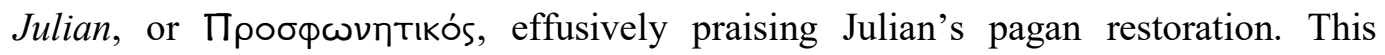
oration reflects something of the high hopes Julian had upon his entrance to the city in July $362 .{ }^{22}$ Julian's narrative in his autobiographical myth must have been attractive to his contemporaries, as Libanius reflected his story in this oration. Libanius first borrowed from Julian's tale of the purge that almost took his life in $O r .7$ to describe his 'spark of prophetic fire' ( omıvөńp) that narrowly escaped the unbelievers. ${ }^{23}$ When Julian first sampled Hellenic philosophy, he 'heard of the gods who fashioned and maintain the universe' (Or. 13.12), gods who later 'led your intellect to greatness through the study of Plato' (Or. 13.13). These divinities then took a more active role, mixing in divine and nautical metaphors: 'They both prepared for you the sceptre and presented you salvation. Now when the sea surged from vexatious winds and ships were sinking and overwhelmed and waves came over the rails, they sent the Dioscuri from their joint council-chamber on high and drew your ship from the surf'

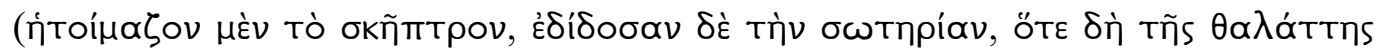

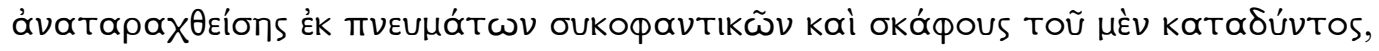

22 Amm. 22.9.14; J. Matthews, The Roman Empire of Ammianus (London, 1989), 108, contra Seeck (n. 6), 210. Julian later looked back on his initial optimism and generous treatment of the city, recalling his plans to make Antioch 'greater and more powerful'. Julian, Or. 12 367cd (Misopogon); cf. M. Gleason, 'Festive Satire: Julian's Misopogon and the New Year at Antioch', JRS 76 (1986), 106-19.

23 Compare the parallel at Julian, Or. 7 229d (To the Cynic Heracleios); cf. Greenwood (n. 1), 142. Julian's Or. 7 is treated in detail in section III of this paper. 


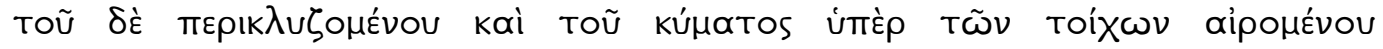

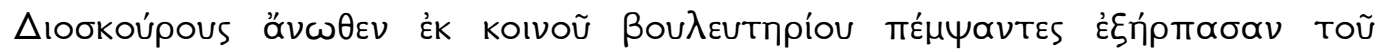

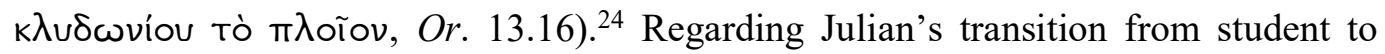
ruler, Libanius concluded that these events in Julian's accession to power showed that

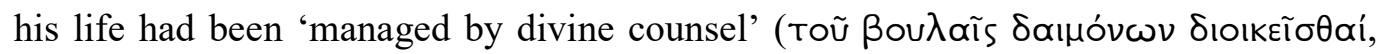
Lib., Or. 13.20). He wrote that once Constantius II elevated Julian to the rank of Caesar, the beginning of his tasks was like his 'first voyage' ( $\pi \rho \tilde{\omega} \tau о \nu ~ \pi \lambda \varepsilon \dot{\varepsilon} \omega \nu, O r$. 13.22). More specifically, Libanius gave the credit for removing Constantius to "The

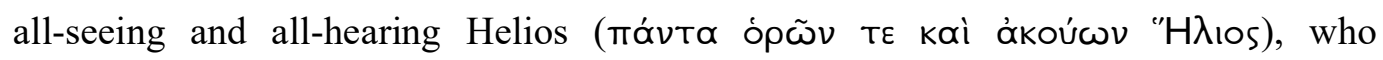
answered the prayers of the Hellenes and removed Constantius, replacing him with

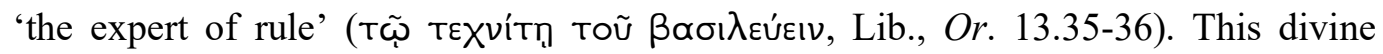
consent incidentally removed any potential stigma as a usurper from Julian's reputation. ${ }^{25}$ The depiction of Julian as a TEXvítns recalls Plato's description of the

24 While it does not affect Libanius' use of Julian's nautical metaphor, the possibility exists that this refers back to Julian's travails in the purge of 337 . Wiemer (n. 6), 89 regards this passage as an allegorical retelling of Eusebia's rescue of Julian following Constantius' execution of Julian's half-brother Gallus. While Wiemer is correct that Libanius generally follows the chronological sequence in Julian's life from beginning studies in 340/41 (13.9) to going to Athens in 354 (13.18), I believe that Libanius' non-chronological parallel with Julian's Or. 7 at 13.11 leaves both possibilities open.

$25 \quad$ Wiemer (n. 6), 101. 
Pilot as a provider of his TÉXv to those he ruled. ${ }^{26}$ Libanius then made the

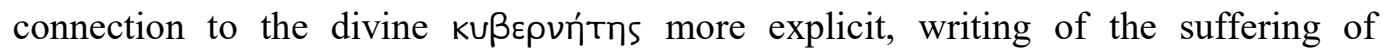
humanity prior to Julian's restoration, which could also be seen as 'the giving back of the gods as guardians to men, as for long, the race, without its great pilots, has been

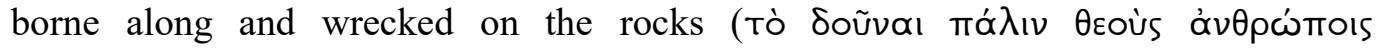

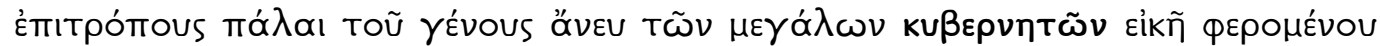

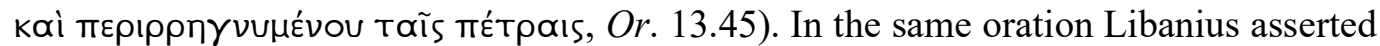
that this was a wonderful time for humanity, tying this to the presence of a human/divine ruler like Zeus. In praising Julian for his frugality and his choice of wise Platonist counsel, Libanius inserted a direct comparison to Zeus: 'As Justice is sitting

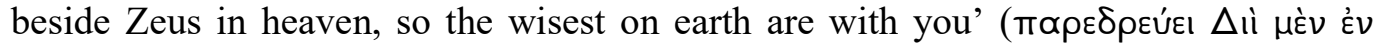

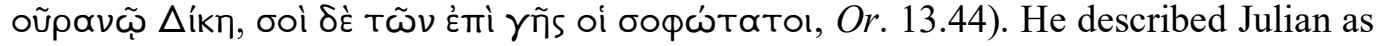

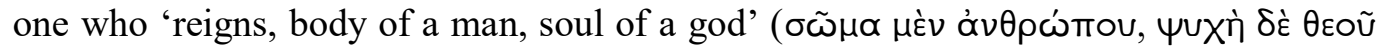
$\beta \propto \sigma ı \lambda \varepsilon \cup ́ \varepsilon l, O r .13 .47) .{ }^{27}$ Libanius held that the situation could not be improved, 'even if Zeus, taking for himself the form of a man, chose to govern all the nations, his

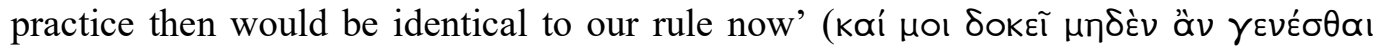

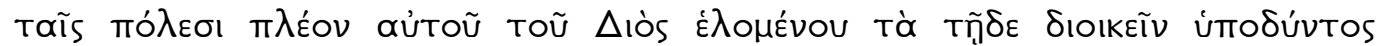

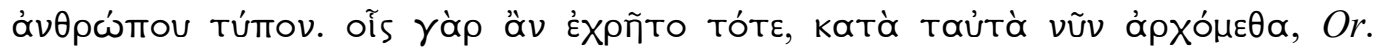
13.47). This direct relationship with the divine was a distinctive feature of Julian's

26 Although Libanius used this term elsewhere in a different sense, his use in this context and in parallel with Julian's turns as the son of God, respectively Heracles, Asclepius, and Christ (see nn. 1,2) strengthens the Platonic connection.

27 Described similarly in Plato's myth, which C.H. Kahn, 'The myth of the Statesman', in C. Partenie, ed. Plato's Myths (Cambridge, 2009), 206-38, at 152, describes as the true statesman being more divine than human. 
reign, and something which Wiemer quite rightly points out is tied to Or. 13.48, where Julian receives direct prophecy in place of the Pythia. ${ }^{28}$ Yet beyond this, Libanius is returning to his theme of Julian's special status as hinted at in Julian's Or. 7.

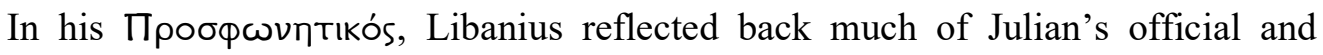
public line, making use of a nautical metaphor. Following the apostasy of Constantine, the people of the empire suffered greatly without their divine pilots. Julian's study of philosophy, particularly Plato, led him to the gods who fashioned and maintained the universe. It was Zeus-Helios' divine plan that he might be spared for his eventual role as the chosen deliverer of his people in place of the apostate Constantius II. This divinely endorsed ruler was human and divine, and would be the earthly ruler on behalf of Zeus-Helios. But behind Libanius, was there another hand on the tiller of this nautical metaphor?

\section{JULIAN AS SOURCE AND SUBJECT}

Julian's campaign to restore pagan religion and sacrifice (A.D. 361-3) rested not only on his authority as an emperor, but also on his exhortations. In them, he carefully presented himself as a figure who would save his people by bringing the empire back to worship of the gods, most notably the god he claimed was his father, Zeus-Helios. Orators loyal to Julian reflected other aspects of this back in their own public addresses while Julian lived, and did so using language that would have resonated with an audience educated in the Hellenic tradition. By alluding to Julian as the quasi-

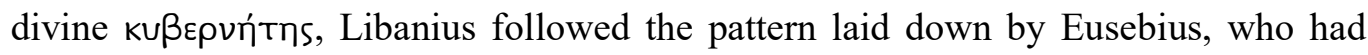
portrayed his emperor Constantine as both a Mosaic saviour-figure, and also an

$28 \quad$ Wiemer (n. 6), 111. 
earthly parallel to the heavenly Christ. ${ }^{29}$ However, Libanius filled this particular framework of human-divine assimilation with resolutely Hellenic content. T. R. Glover suggested that Julian had cast himself in something of this pilot role, writing of the emperor that: 'He might indeed be himself the chosen messenger of heaven, for it was a Neo-Platonic doctrine that the gods stoop to give mankind a saviour and a regenerator whenever the divine impulse in the world is in danger of being exhausted' ${ }^{30}$ In support of this, Glover cited Synesius, who wrote 'For prescribed times then bring them down after the pattern of machinists, giving an initial positive

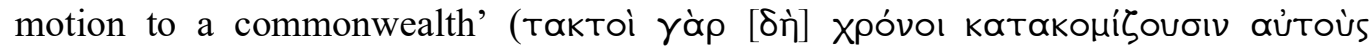

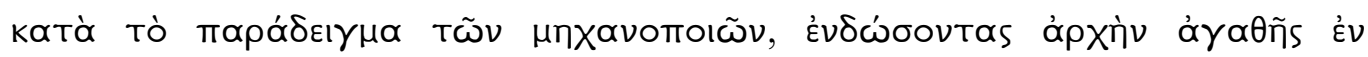

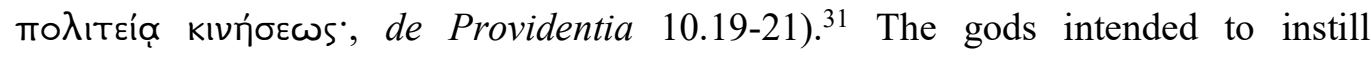

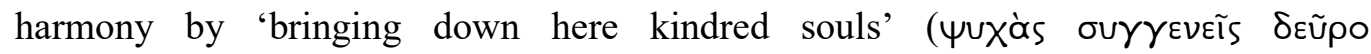
катаконі́баvтєs, de Providentia 10.23).

Julian is primarily remembered for his rejection of Christianity, and his opposition to the Christianization of his uncle Constantine. However, this negative

29 Eusebius cast Constantine as a Mosaic saviour-figure in Vit. Const. 1.3.17, 1.12.2, 1.20.2, 1.27.2-3, 1.18.1-2, 1.31.3; cf. A. Cameron and S. Hall (tr.), Eusebius, Life of Constantine (Oxford and New York, 1999), 35-8, and as a mimetic Christfigure in de Laud. 2.2-5, 3.4, 6.9, 7.13; cf. H. Drake (tr.), Eusebius, In Praise of Constantine: A Historical Study and New Translation of Eusebius' Tricennial Orations (Berkeley, 1976), 75. For that matter, this was not unlike the Ptolemy's title

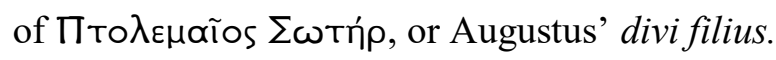

30 T. R. Glover, Life and Letters in the Fourth Century (Cambridge, 1901), 58.

31 While admittedly Synesius post-dates Julian (b. A.D. 370), this highlights the trend in Neoplatonic thought. 
portrayal needs to be balanced with a positive assessment of what Julian chose to stand for. As emperor, Julian not only promoted a restoration of traditional religion and sacrifice, he wrote extensively as a Neoplatonic philosopher. ${ }^{32}$ While his stature has been maligned by some modern scholars, both John Dillon and Andrew Smith have written appreciatively of the strengths of Julian's presentation of Neoplatonism. ${ }^{33}$ Julian was a particular follower of Plato. In a letter to his confidant Oribasius, he described himself as a 'zealous student' of Plato and Aristotle (Ep. 14 385b). Julian also advised his friends Eumenius and Pharianus to focus all their efforts on understanding these two writers, and wrote to his uncle that for a period his only books were Homer and Plato. ${ }^{34}$ In his magisterial study of Julian's influences, Jean Bouffartigue has tabulated 81 instances of Julian citing Plato's works. ${ }^{35}$ As a Roman emperor, Julian was well placed to take advantage of the concept of emperor worship, a concept that continued research, particularly into material evidence, has

32 Cf. Or. 7 To the Cynic Heracleios; Or. 8 Hymn to the Mother of the Gods; Or.

\section{Hymn to King Helios.}

33 Dillon (n. 21), 103-115; A. Smith, 'Julian's Hymn to King Helios: the economical use of complex Neoplatonic concepts' in N. Baker-Brian and S. Tougher (eds.), Emperor and Author: The Writings of Julian the Apostate (Swansea, 2012), 229-35. M. Carmen de Vita, 'Philosophiae magister: Giuliano interprete di Platone', Atti Accademia Pontaniana, Napoli 51 (2012), 106, cautions that although Julian was unique as a 'philosopher militant', he was not, properly speaking, a philosopher.

$34 \quad$ Julian, Ep. 8.441c; Ep. 80.

35 J. Bouffartigue, L'Empereur Julien et la culture de son temps (Paris, 1992), 170. 
demonstrated was widespread and taken seriously. ${ }^{36}$ As one scholar has noted of the Roman emperor, 'they sacrificed to him, as though he was a god, and perhaps they covered the conflict of evidence with a metaphysical metaphor - god made manifest, son of god, the least of gods but highest of mortals' ${ }^{37}$

While the modern imagination has been much more captivated by the overt democratic displays of the emperor who publicly left his seat to embrace a philosopher, in practice, Julian's rule consistently embodied theocratic kingship. Julian was certainly not alone in this, although his particular approach may have been unique. His actions were directly in line with those of his neo-Flavian predecessors Constantine and Constantius II. As noted by Athanassiadi, Julian sought ways of 'linking the new political theology propounded by his own family to the ideals of Hellenism and Romanitas'. ${ }^{38}$

In the period before his sole rule, the emperor wrote two works that reveal his theory of the ideal ruler. Julian's definition of the ideal statesman is prominently

36 E.g., S. Price, Rituals and Power: The Roman Imperial Cult in Asia Minor (Cambridge, 1984); I. Gradel, Emperor Worship and Roman Religion (Oxford, 2002); C. Ando, The Matter of the Gods: Religion and the Roman Empire (Berkeley, 2008). Although Julian initially rebutted divine rulership in his Ep. Them., Themistius' response addressed those points in a way that Julian seems to have taken on board by the time of his Or. 3 (see pp. 000-000 below).

37 K. Hopkins, Conquerors and Slaves: Sociological Studies in Roman History (Cambridge, 1978), 242.

38 P. Athanassiadi, Julian and Hellenism: An Intellectual Biography (as Polymnia Athanassiadi-Fowden) (Oxford, 1981); reprinted with new introduction as Julian: An Intellectual Biography (London, 1992), 113. 
displayed in his Or. 6 Epistle to Themistius. ${ }^{39}$ Julian wrote that the theme of his letter was that a human ruler must exhibit divine conduct, and later tied this need for a ruler with divine character to the teachings of Plato. ${ }^{40}$ This letter is frequently viewed as a conclusive slamming of the door on Themistius' suggestion that the role of philosopher and king should be united, ${ }^{41}$ although Themistius' apparent response, which has survived in Arabic, argued that a rational man forgoing sensual pleasures could become that prescribed divine ruler. ${ }^{42}$ In Julian's Or. 3 The Heroic Deeds of 39 While there is no consensus regarding dating, scholarship largely supports the occasion being Julian's becoming Caesar in 355; e.g. S. Bradbury, 'The date of Julian's Letter to Themistius', GRBS 28 (1987), 235-51, J. Bouffartigue, 'La lettre de Julien à Thémistios: histoire d'une fausse manœuvre et d'un désaccord essentiel',in A. Gonzalez Galvez and P.-L. Malosse (eds.), Mélanges A. F. Norman, Topoi, Suppl. 7, 2006, 113-38 at 120-7 ; S. Swain, Themistius, Julian, and Greek Political Theory under Rome: Texts, Translations, and Studies of Four Key Works (Cambridge and New York, 2013), 56-7. T.D. Barnes and J. Vanderspoel, 'Julian and Themistius', GRBS 22 (1981), 187-9 and T. Brauch, 'Themistius and the emperor Julian', Byzantion 63 (1993), 79-115 at 85-8 suggest that it was written at that time, but published in 361 when Julian became sole Augustus in 361. Others, such as U. Criscuolo, 'Sull' epistola di Giuliano imperatore al filosofo Temistio', Koinonia 7 (1983), 89-111 at 91, argue for both writing and publication in 361.

$40 \quad$ Julian, Or. 6.259a; 260d (To Themistius).

$41 \quad$ E.g., Bouffartigue (n. 37), 127-8, 136-7.

42 Themistius, Risāla 1.82.2-2.84.15; cf. J. Croissant, 'Un nouveau discours de Thémistius', Serta Leodiensia, Bibliothèque de la faculté de philosophie et lettres de l'université de Liège 44 (Liège and Paris, 1930), 7-30; J. Watt, 'Julian's Letter to 
Constantius, or On Kingship, he painted a picture of the ideal ruler, one which is arguably tailored to Julian himself rather than Constantius. ${ }^{43} \mathrm{He}$ describes this ideal

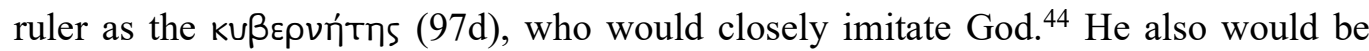

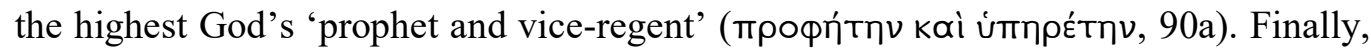
he bore the title previously used by Eusebius of Caesarea to describe Constantine,

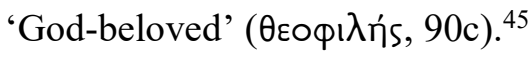

Themistius - and Themistius' response?', in N. Baker-Brian and S. Tougher (eds.), Emperor and Author: The Writings of Julian the Apostate (Swansea, 2012), 91-103 at 97; and see now the edition of Swain (n. 41).

43 H. Drake, “"But I digress...”: Rhetoric and propaganda in Julian's second oration to Constantius', in N. Baker-Brian and S. Tougher (eds.), Emperor and Author: The Writings of Julian the Apostate (Swansea, 2012), 35-46 at 41-2; cf. Athanassiadi (n. 40), 66, who describes Julian's work as a 'panegyric of his own deeds'. It must be dated after the lowland campaigns mentioned, but probably before the end of the peace with Persia (56b, 66d), suggesting to me summer 358; cf. Drake, 39. F. Curta, 'Atticism, Homer, Neoplatonism, and Fürstenspiegel: Julian's second panegyric on Constantius', GRBS 36 (1995), 177-211 at 196, argues for a date as late as 360 .

44 Or. 3 97d, 100d (The Heroic Deeds of Constantius, or On Kingship).

45 While some might see this epithet as too ubiquitous to be significant, it is surely important that Julian's uncle Constantine, whom Julian reacted against so resolutely, was written about so much in this vein, e.g. 'the sovereign dear to God, in imitation of the higher power, directs the helm and sets straight all things on earth', Eus., De Laudibus Constantini 1.6 (trans. Drake); cf. Eus., Vit. Const. 1.1.6; 3.1.8; 3.49 . 
Once Julian had engineered his acclamation as Augustus and was marching to confront his cousin Constantius II, he would put his theories on the theme of rulership into his writing for a public audience. ${ }^{46}$ His Or. 5 To the Senate and People of Athens contrasted the ethics of and attitudes towards rule of the tyrannical Constantius and the ethical Julian. Following Constantius' untimely death which left Julian sole and uncontested ruler, the emperor's Or. 7 To the Cynic Heracleios, written in Spring 362, similarly contrasted the self-centered Constantine, whose apostasy would drag down the people he ruled, to the selfless and pious Julian, who would restore the empire. ${ }^{47}$ Julian embedded an autobiographical myth in his $O r .7$ which was a response to the impertinent Cynic philosopher Heracleios. In this myth, he crafted a role for himself as the divine figure sent to earth to put things right, to restore the human-divine balance that the apostate Constantine had destroyed, bringing the abandonment of the gods and suffering upon his house and race. ${ }^{48}$ Julian discussed his own view that

46 For analysis of the manipulated acclamation, see I. Müller-Seidl, 'Die Usurpation Julians des Abtrünnigen im Lichte seiner Germanenpolitik', HZ 180 (1955), 225-44 at 241-4; K. Rosen, 'Beobachtungen zur Ehrebung Julians 360-361 n. Chr.', AClass 12 (1969), 121-49.

$47 \quad$ Libanius, Or. 18.157 (Funeral Oration over Julian) places the composition of Julian's Or. 7 at the same time as his Or. 8 To the Mother of the Gods, in which Julian's statement at 161c dates that work to the festival of Cybele in March 362.

48 Julian, Or. 7.219d-220a; 228d-229a; 229c-230a (To the Cynic Heracleios).

For dating, see: G. Rochefort, ed., L 'empereur Julien. Oeuvres complètes, vol. 2.1, (Paris, 1963), 36; R.B.E. Smith, Julian's Gods: Religion and Philosophy in the Thought and Action of Julian the Apostate (London, 1995), 89; R. Guido (ed.), Giuliano l'Apostate: al cinico Eraclio (Galatina, 2000), viii. 
myth can be appropriately used by philosophers, and even cited philosophers of whom he approved who had used myth (Or. 7.215bc, 209a). Intriguingly, Julian stated that for safety's sake, one may be forced to express oneself through myth (Or. 7.207e). Julian claimed to be the son of Zeus-Helios, and was offered the stewardship of the empire on behalf of the gods (Or. 7.232c). Julian's father explained that his mission was one of restoration: 'You must return and cleanse all the impiety, and

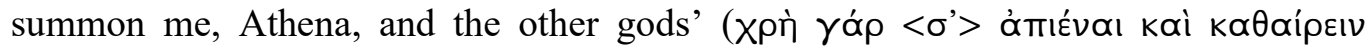

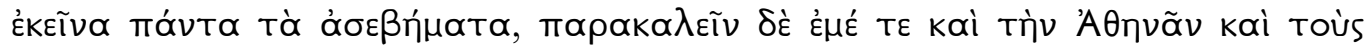

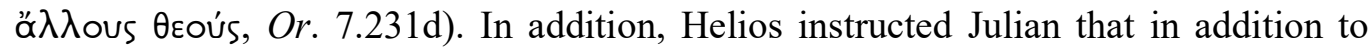
piety, he was expected to be "philanthropic towards the subjects, ruling them and

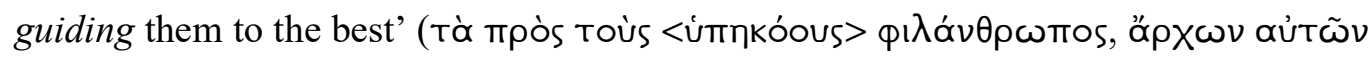

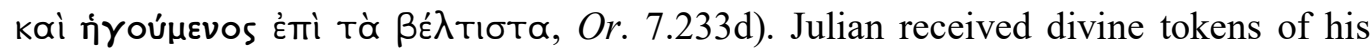
own from the gods, signifying their protection, his kingship, and his status as a divine representative. ${ }^{49}$ His divine encounter ended with Helios informing him, 'Now know

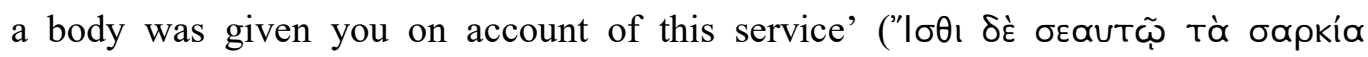

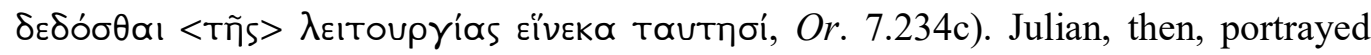
himself as a divine figure given a body and tasked with serving the gods by taking the helm of empire, restoring traditional religion, and guiding his people towards the good.

49 Julian, Or. 7.234ab (To the Cynic Heracleios); cf. Athanassiadi (n. 40), 172, 174; G. Glazov, The Bridling of the Tongue and the Opening of the Mouth in Biblical Prophecy (Sheffield, 2001), 107-8. 


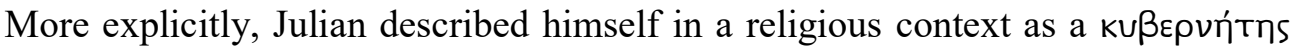
in a letter sent to one of his Neoplatonic priests at the end of A.D. $361{ }^{50}$ Julian first established that he was writing out of a need for assistance in regards to their pursuit of a common good, the health of their religion. As the emperor explained to his high priest Theodorus (Ep. 30):

Therefore, it is necessary that you take your place and through your letters zealously advise the things to be done. For we can see that in the case of those leading in war it is not those living peaceably needing alliance, but, I believe, the ones toiling in the fight, and in the case of pilots, those at anchor do not summon those sailing, but those under sail lead out those who are at rest. ${ }^{51}$

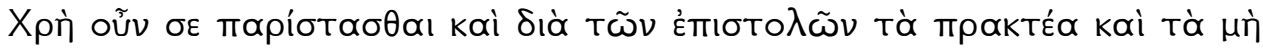

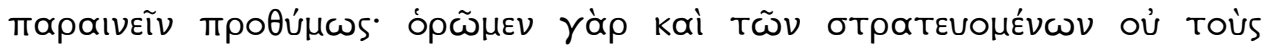

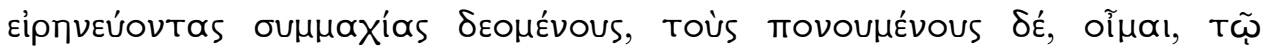

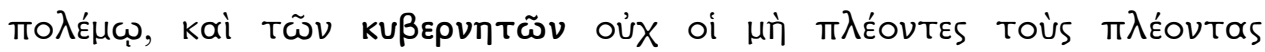

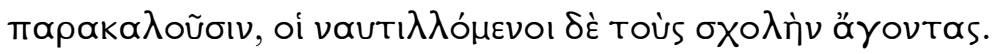

50 Julian, Ep. 30; J. Bidez (ed.), L 'empereur Julien. Oeuvres complètes tom. 1, part. 2, Lettres et Fragments (Paris, 1924), 35. J. Bidez and F. Cumont (eds.), Iuliani epistulae leges poemata fragmenta varia (Oxford and Paris, 1922), v, note that Libanius was a likely candidate for editor of Julian's letters.

51 'Those at anchor' is of course, literally 'those not sailing', but that makes for a rather confusing translation. 
Both Athanassiadi and Bidez note Julian's marked preference for theurgic Neoplatonists among his priests. ${ }^{52}$ Theodorus was the high priest of Asia, and had been a fellow pupil of Maximus with Julian. ${ }^{53}$ Julian was ordering Theodorus to get into the fight and help him in the war between traditional Hellenic religion and Christianity. This passage does not directly attribute divinity, but the context suggests the role of the head of state and high priest leading in a religious war. Given this, the

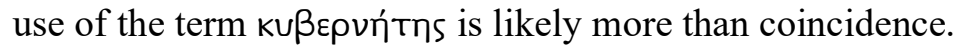

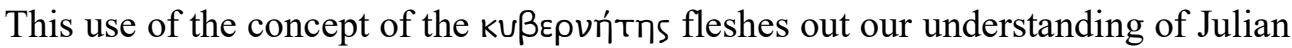
and his concept of theocratic rule. Julian had presented himself as something of a Hellenic saviour figure, first recasting Heracles as a Christ-figure, the son of ZeusHelios, then identifying himself as the son of Zeus-Helios, and assimilating himself to Heracles. ${ }^{54}$ This was recognised and reflected in the orations and writings of Libanius of Antioch and Eunapius of Sardis. ${ }^{55}$ In Libanius' later Or. 12, delivered on 1 January 363, he did not return to the theme of the 'divine' pilot. This is not a change of direction as much as emphasis, as by re-using the pilot at all, Libanius alluded to his previous application which combined both statesman and divine figure. The shift in

52 Athanassiadi (n. 40), 185; J. Bidez, La vie de l'empereur Julien (Paris, 1930), 267. As Christianity had offered an alternate respectable career, so Julian took the opportunity to offer the same patronage to Neoplatonists.

53 Julian, Ep. 30; 89a.452d; Ep. 89a.452a; 89b.298b; cf. Jones, et al. (n. 6), 897, s.v. Theodorus 8 .

${ }^{54}$ Julian, Or. 7.229c, 232d (To the Cynic Heracleios); Or. 10.336a (Caesares); Or. 11.157a (Hymn to King Helios).

55 Libanius, Or. 13.11; Or. 12.28, Or. 18.87; Eun., frags. 28.5, 28.6 Blockley; cf. Athanassiadi (n. 40), 168. 
emphasis may be explained by Julian's interest in assimilating himself to a Christ-like Asclepius, the son of Zeus-Helios, in a similar fashion in his Against the Galilaeans, written in winter 362-3, and Or. 11 Hymn to King Helios, written in December $362 .{ }^{56}$ In the use of this Platonic theme, however, there is no subterfuge and no supplanting, as Plato's kußepvítns was drawn from the Hellenic literary tradition. This demonstrates both Julian's embracing of the idea of the divine statesman, and the approving reflection of Libanius, who was not overly philosophically inclined himself, but was a politically astute advocate for his emperor. Julian seemed to have taken on board Messianic aspects of his Christian upbringing, but here synthesized and applied that within a purely Hellenic framework.

\section{CONCLUSION}

I have argued that just as Plato's use of the concept of the pilot could be taken as both a political and a metaphysical metaphor, so was Julian's use of it and Libanius' reflection of it. While both had used the term in its broader sense more widely, use of the concept to portray someone as a divine restorer was reserved for Julian. Amidst a

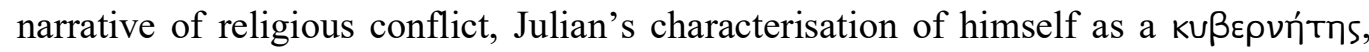
reflected in the writings of his close followers, was a remarkable stratagem, portraying Julian as possessing a divine soul, and being a divinely ordained restorer figure for Hellenes. While the usage could of course be happenstance, Libanius'

56 Julian, Or. 11.144b, 153b (Hymn to King Helios); Against the Galilaeans 200ab; a concept that Libanius reflected back in language of Julian as 'healer', Or. 15.69, 17.36, 18.124-25, 281; cf. Greenwood, ‘Julian's Use of Asclepius' (n. 1). 
previous adoption of Julian's line in this area suggests otherwise. When Julian presented himself as divine, as Heracles, and as Asclepius, he was followed by his

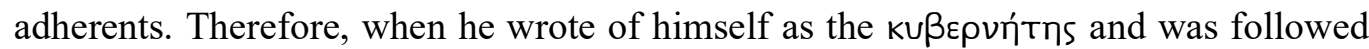
in this by his adherents, it should be taken as an important component of his rhetoric of rule, and perhaps also a glimpse into his genuine self-understanding.

\begin{tabular}{|l|r|}
\hline University of Aberdeen & DAVID NEAL GREENWOOD \\
\hline & dngreenwood@abdn.ac.uk \\
\hline
\end{tabular}

